\title{
Effect of processing variables and in-vitro study of microparticulate system of nimesulide
}

\author{
Kamlesh Dashora, Shailendra Saraf, Swarnlata Saraf* \\ Institute of Pharmacy, Pt. Ravishankar Shukla University, India
}

*Correspondence:

Swarnlata Saraf

Reader

Institute of Pharmacy

Pt. Ravishankar Shukla University,

Raipur (C.G.)

492 010-India

E-mail: swarnlata_saraf@rediffmail.com
Microparticulate systems of nimesulide (NIM) were prepared by modified solvent evaporation method using different variables such as polymer: drug (NIM) ratios (cellulose acetate, CA: nimesulide, NIM) (1:9, 1:6 and 1:3), agitation speeds (500-1500 rpm) and stirring time (15-30 min). The effects of processing variables were evaluated by microparticle size and entrapment efficiency. The average microparticle size increases from $66.8 \pm 1.45$ to $87.3 \pm 1.06 \mu \mathrm{m}$ with increase in the polymer concentration while reduces with increase in agitation speed and stirring time; but at the too higher speed gives irregular shape of particles. The highest entrapment efficiency $(77.83 \pm 0.51 \%)$, size uniformity, free flowability, i.e., angle of repose $\left(23.5 \pm 0.4^{\circ}\right)$ and compressibility index $(14.2 \pm 0.6 \%$ ), of microparticles were found with 1:6 (polymer: drug ratio), at $1000 \mathrm{rpm}$ and $20 \mathrm{~min}$ stirring time among all prepared microparticles $(P \leq 0.05)$. The in-vitro drug release study of microparticles with optimized processing variables (agitation speed and time) were carried out and compared with conventional and marketed SR tablets. The conventional tablet releases maximum drug within $4 \mathrm{~h}$ while microparticulate system releases more than $14 \mathrm{~h}$. All formulations followed first order release kinetic and diffusion controlled drug release (Higuchi model). These microparticles are stable at room temperature $\left(25 \pm 1^{\circ} \mathrm{C}\right)$ but agglomerate at elevated temperature $\left(50 \pm 1^{\circ} \mathrm{C}\right)$ by softening and fusion of the polymer observed under SEM study.
Uniterms

- Cellulose acetate

- Microparticles

- Nimesulide

\section{INTRODUCTION}

Microencapsulation is a well known method for the preparation of controlled or extended release dosage forms. Different coating materials and processes are used for microencapsulation of drugs. The literature reviews showed the different criteria for the designing of microparticles according to polymer properties (Bayomi 2004; Sajeev et al., 2002). Cellulose acetate (CA) is a water insoluble cellulosic polymer and commonly used for the formulations of microparticles, pellets and beads for the delivery of prolonged and sustained therapy (Soppimath et 
al., 2001). In the present work cellulose acetate (CA) is chosen as suitable polymer for encapsulating the nimesulide by solvent evaporation technique. Nimesulide (NIM) is described chemically as $\mathrm{N}$-(4-nitro-2phenoxyphenyl)methane sulfonamide. It is a unique nonsteroidal anti-inflammatory (NSAID) agent having specific affinity to inhibit cyclooxygenase-2 enzyme (Rabasseda 1992). It is highly effective in reducing pain associated with osteoarthritis, rheumatoid, and other degenerative joints disorders, low back pain, dysmenorrhoea, gynaecological condition, thrombophlebitis, dental pain and inflammations etc. (Bernareggi, 1993; Kulkarni, 2002). This drug is also associated with some severe side effects due to higher doses such as epigastric pain, heartburn, nausea, diarrhoea, vomiting, peptic ulcer and hepatic impairments. Nimesulide attain peak serum concentrations of 1.98 to $9.85 \mathrm{mg} / \mathrm{L}$ within 1.22 to 3.17 hours when given orally and extensively bound to plasma proteins ( $99 \%$ ) having half-life 1.56 to $4.95 \mathrm{hr}$ which requires frequent dosing to maintain plasma concentration (Boelsterli, 2002; Peruccae, 1993; Singla et $a l ., 2000)$. The objective of this study is to develop sustained release formulation with lower dose of drug to maintain plasma concentration that may increase patients compliance, improved therapeutic efficacy and reduced severity of upper GI side effects because of alteration in delivery pattern via slow release of drug from microparticles.

\section{MATERIAL AND METHODS}

\section{Material}

Nimesulide B.P. received as gift sample from Nicholas Piramal India Ltd, Pithampur M.P.), cellulose acetate from Zeim Lab. Nagpur. The chemicals such as acetone, methanol, liquid paraffin (heavy and light) and nhexane, were of analytical grade supplied by Merck Chem. Ltd.

\section{Preparation of microparticles}

NIM microparticles were prepared by using cellulose acetate polymer as a retardant material and any interaction to the drug was studied by IR spectra.

The microparticles of nimesulide were prepared by modified emulsion solvent evaporation method with modifications (Olive, Rey, 1993; Chowdhary, Ramesh, 1995; Saravanan et al., 2003; Saraf et al., 2006; Dashora et al., 2006a) using polymeric solution (CA) with the different polymer: drug ratio $(1: 9,1: 6$ and $1: 3)$ in $10 \mathrm{~mL}$ acetone. This solution was dispersed in a thin stream to previously heated liquid paraffin (1:1 light and heavy, $600 \mathrm{~mL}$ at $60 \pm 3{ }^{\circ} \mathrm{C}$ ) in a $1000 \mathrm{~mL}$ beaker with stirring rate at 500-1500 rpm. A Remi medium duty stirrer was used for stirring and continued for 15 - 30 minutes to disperse the added mixture as fine droplet emulsion. The solvent was removed by evaporation at room temperature $\left(30 \pm 1{ }^{\circ} \mathrm{C}\right)$ under vacuum ( 0.80 torr) for 1.0 hour to produce almost spherical microparticles (projection microscope, Quasmo, India). The microparticles were collected by decantation and washed with $n$-hexane to remove adhering liquid paraffin. The product was then dried to obtained discreet microparticles. Microparticles were prepared using different polymer: drug ratios 1:9,1:6 and 1:3 (NIM-1, NIM-2 and NIM-3), while keeping the other two variables constant i.e. stirring speed $1000 \mathrm{rpm}$ and stirring time $20 \mathrm{~min}$. Similarly, microparticles were also prepared at different stirring rate viz. 500, 1000 and 1500 rpm, keeping the polymer: drug ratio 1:6 and stirring time $20 \mathrm{~min}$. In the same way microparticles were prepared using different stirring time i.e. 15, 20 and $30 \mathrm{~min}$, keeping the polymer: drug ratio 1:6 and stirring speed $1000 \mathrm{rpm}$.

\section{Characterization of microparticles}

Infrared spectra of NIM and NIM loaded microparticles were determined in the range of 4700 to $400 \mathrm{~cm}^{-1}$ using a Fourier-transform infrared spectrophotometer (FT-IR) (model FTIR-8400 S Shimadzu, Japan) from $\mathrm{KBr}$ pellets.

The surface morphology of microparticles was performed by a scanning electron microscopy (SEM, LEO 430, London). Microparticles were mounted on stubs and coated for $120 \mathrm{~s}$ with a layer of gold using a sputter coater. The size of microparticles was determined by an optical microscopy using a calibrated ocular micrometer (Erma, Japan).

Stability studies were conducted to find out stable product under storage. The microparticles were stored in amber colored glass bottles at elevated temperature i.e., $4 \pm 1{ }^{\circ} \mathrm{C}$ freezing temperature (FT), $25 \pm 1{ }^{\circ} \mathrm{C}$ room temperature (RT) and $50 \pm 1{ }^{\circ} \mathrm{C}$ hot temperature (HT) for a period of 30 days and observed for change in drug content and morphology, i.e. shape and structural integrity, by microscopic and scanning electron microscopy.

\section{Drug content}

After stipulated time of storage, an accurate weighed quantity of microparticles $(200 \mathrm{mg}$ ) was taken and finely powdered. The powdered amount equivalent to $50 \mathrm{mg}$ of NIM was extracted in $10 \mathrm{~mL}$ methanol and $20 \mathrm{~mL}$ of 
pH 6.8 buffer. The insoluble polymer was separate out through the Whatman $(0.45 \mu \mathrm{m})$ filter paper. The supernatant was assayed spectrophotometrically (UV-1700 - Shimadzu Japan) after suitable dilution at $397 \mathrm{~nm}$ by using modified method of Dashora et al. (2006b). The percentage of nimesulide remained was calculated by using equation ( $\mathrm{A}=0.3474$ Conc. $+0.0353, \mathrm{R}^{2}=0.999$, where $\mathrm{A}$ and $\mathrm{R}^{2}$ indicates absorbance of test solution in phosphate buffer of pH 6.8 and regression coefficient of calibration curve of nimesulide respectively). Each determination was made in triplicate.

\section{Entrapment efficiency of microparticles}

An accurately weighed quantity of microparticles (equivalent to $50 \mathrm{mg}$ NIM) was extracted in $10 \mathrm{~mL}$ methanol and $20 \mathrm{~mL}$ of $\mathrm{pH}$ 6.8-phosphate buffer for $24 \mathrm{~h}$. Coating polymeric material is separated out through the Whatman $(0.45 \mu \mathrm{m})$ filter paper. The polymer was washed three times $(7 \mathrm{~mL}$ each time) with buffer and all filtrates were added and assayed spectrophotometrically (UV-1700Shimadzu Japan) after suitable dilution at $397 \mathrm{~nm}$. The concentration of drug in filtrate was determined from the calibration curve of NIM in alkaline phosphate buffer $\mathrm{pH} 6.8$ and encapsulation efficiency for microparticles was calculated by using equation $(\mathrm{A}=0.3474$ Conc. +0.0353 , $\mathrm{R}^{2}=0.999$, where $\mathrm{A}$ and $\mathrm{R}^{2}$ indicates absorbance of test solution in phosphate buffer of $\mathrm{pH} 6.8$ and regression coefficient of calibration curve of nimesulide respectively). Each determination was made in triplicate.

Flow properties of the microparticles were evaluated by determining the angle of repose by fixed funnel and free standing cone method and the compressibility index by tapped density method.

\section{Drug release studies}

The USP method II or paddle dissolution test (Model No. USP TDT -06P, Electrolab), was used with a pH 6.8 phosphate buffer as the release medium. The stirring speed was $100 \mathrm{rpm}$ and the temperature of the release medium was kept at $37 \pm 0.5^{\circ} \mathrm{C}$. An accurately weighed amount of microparticles equivalent to $100 \mathrm{mg}$ of NIM was added to $900 \mathrm{~mL}$ of dissolution medium and methanol was included in the dissolution medium to provide a sink condition, in order to kept the drug below the $10 \%$ of the saturation value (Dashora et al., 2006c). At programmed intervals, $5 \mathrm{~mL}$ samples were withdrawn and filter through $0.45 \mu \mathrm{m}$ Whatman filter and assayed spectrophotometrically at $397 \mathrm{~nm}$ using modified method after suitable dilution (Dashora et al., 2006b). An equivalent quantity of dissolution medium was added at all the withdrawal of sample. The mean of six determinations was used to calculate the drug release from each of the formulation.

\section{Release kinetics}

In the present study, two different mathematical equations (Martin, 1983) were employed to model the dissolution profile from the NIM microparticles system i.e., (1) first order equation; (2) Higuchi's square root of time equation.

(1) First order model can be expressed as

$$
\mathrm{M}_{\mathrm{t}} / \mathrm{M}_{\infty}=1-\mathrm{e}^{-} \mathrm{k}_{1}^{\mathrm{t}}
$$

(2) Higuchi's square root of time model is given by

$$
M_{t} / M_{\infty}=k_{H} t^{1 / 2}
$$

Where $M_{t}$ is the amount of drug released at time t, $M_{\infty}$ is the maximal amount of drug released at infinite time, $\mathrm{k}_{1}$ and $\mathrm{k}_{\mathrm{H}}$ are the rate constants for first order and Higuchi model, respectively.

\section{RESULTS AND DISCUSSION}

In order to study the interaction between NIM and polymer (CA), IR studies were performed using $\mathrm{KBr}$ pellet press method. The IR spectra of the NIM indicated the presence of bands at about $900-640 \mathrm{~cm}^{-1}$ (C-H aromatic), $1080 \mathrm{~cm}^{-1}(\mathrm{~S}=\mathrm{O}), 1160 \mathrm{~cm}^{-1}$ (C-O-C ether linkage), $1140 \mathrm{~cm}^{-1}$ (CH3 C-H bending), 1520 and $1350 \mathrm{~cm}^{-1}$ (NO2), $2940 \mathrm{~cm}^{-1}$ (CH3 C-H stretching) and $3280 \mathrm{~cm}^{-1}(\mathrm{~N}-\mathrm{H})$. IR spectra of NIM loaded microparticles of CA also showed the peaks at the same bands. This indicated that there is no interaction between NIM and polymers employed in the microparticles.

The effect of various processing variables of microparticles like polymer concentration, agitation speed and stirring time were studied on particle size, drug entrapment efficiency and drug release study. When polymer concentration was increased from 1:9 to 1:3 (polymer: drug) ratio then particle size increases from $68.8 \pm 1.45$ to $87.33 \pm 1.06 \mu \mathrm{m}$. The average diameter of the microparticles at various agitation speeds i.e., 500, 1000 and $1500 \mathrm{rpm}$ were found in decreasing order, i.e., $71.1 \pm 1.63$ to $69.1 \pm 1.05 \mu \mathrm{m}$ (Table I). This suggests that the size of the droplets formed during microcapsulation is closely related to the size of final microcapsules, which increased by decreasing the stirring speed. A faster stirring speed $1500 \mathrm{rpm}$ gave much smaller but cohered particles. At lower speed (500 rpm), the mean particle diameter and 
TABLE I - Effects of processing variables on the characteristics of cellulose acetate microparticles containing nimesulide $($ Mean $\pm \mathrm{sd}, \mathrm{n}=3$ )

\begin{tabular}{llll}
\hline Variables/Factor & Parameter & ${\text { Particle size }(\text { average diameter })(\boldsymbol{\mu m})^{\mathbf{d}}}$ & Entrapment efficiency $(\%)^{\mathbf{d}}$ \\
\hline Polymer: drug ratio $^{\mathrm{a}}$ & $1: 9$ & $68.8 \pm 1.45$ & $70.31 \pm 1.05$ \\
& $1: 6$ & $71.1 \pm 0.81$ & $75.66 \pm 1.86$ \\
& $1: 3$ & $87.3 \pm 1.06$ & $66.46 \pm 2.08$ \\
Stirring speed (rpm) $^{\mathrm{b}}$ & 500 & $71.1 \pm 1.63$ & $73.66 \pm 3.15$ \\
& 1000 & $70.2 \pm 1.05$ & $77.63 \pm 1.81$ \\
& 1500 & $69.1 \pm 1.05$ & $72.71 \pm 3.40$ \\
Stirring time (min) & 15 & $78.4 \pm 2.05$ & $70.66 \pm 1.83$ \\
& 20 & $71.2 \pm 1.95$ & $77.83 \pm 0.51$ \\
& 30 & $68.23 \pm 0.87$ & $73.46 \pm 1.95$ \\
\hline
\end{tabular}

${ }^{\mathrm{a}}$ At stirring rate $1000 \mathrm{rpm}$ and stirring time $20 \mathrm{~min} ;{ }^{\mathrm{b}}$ At polymer: drug ratio 1:6 and stirring time $20 \mathrm{~min} ;{ }^{\mathrm{c}}$ At Polymer: drug ratio 1:6 and stirring speed $1000 \mathrm{rpm} ;{ }^{\mathrm{d}}$ Data of average diameter and entrapment efficiency of CA microcapsules were compared statistically using unpaired t-test and one-way analysis of variance (ANOVA) at a significant level $\mathrm{P} \leq 0.05$

size distribution of the microparticles increased considerably. The irregularity in shape of microparticles occurred at higher speed (1500 rpm) but discreet and uniform size of microparticles were obtained at $1000 \mathrm{rpm}$. The average diameter of the microparticles decreases from $78.4 \pm 2.05$ to $68.23 \pm 0.87 \mu \mathrm{m}$ on increasing stirring times from 15 to $30 \mathrm{~min}$. The short time $(15 \mathrm{~min})$ resulted in aggregates and less discreet microparticles where at high stirring time (30 min) resulted smaller microparticles with increased size distribution. The discreet and uniform size of the microparticles was found at $20 \mathrm{~min}$ stirring time.

The maximum entrapment efficiency $(75.66 \pm 1.86 \%)$ was found for NIM-2 formulation. This may be due to that at this polymer: drug ratio, uniform size of drug globules coated with polymer during emulsification process [observed under projection microscope (Quasmo, India)]. The agitation speed affects drug entrapment efficiency of microparticles and it were found to be $73.66 \pm 3.15$, $77.63 \pm 1.81$ and $72.71 \pm 3.40$ with $500-1500 \mathrm{rpm}$ respectively. The lower entrapment efficiency at $500 \mathrm{rpm}$ agitation speed may be due to inadequately stirring of droplets, which leads to increased chances of coalescence. At higher agitation speed i.e., $1500 \mathrm{rpm}$, it was visually observed that most of the globules were forced towards the wall of the flask due to high rotation and it lowers the contact time between polymer and drug molecules. But at $1000 \mathrm{rpm}$, no sticking of polymeric material around the walls of flask was visually observed which may leads to improved drug: polymer contact time resulting highest drug entrapment efficiency. The effect of varying stirring time (15-30 min) was also observed for drug entrapment efficiency and found $70.66 \pm 1.83$ and $73.46 \pm 1.95 \%$ at lower and higher stirring time. The maximum entrapment efficiency $(77.83 \pm 0.50 \%)$ was observed at stirring time 20 min because of sufficient time for tightening of polymeric network around the globules unlike in case of lower and higher stirring time (Table I). The data of entrapment efficiency indicates that approx $23 \%$ of the drug appears to leach out to the external phase (liquid paraffin) during the process and it is confirmed by estimation of residual drug content in external phase. So, microparticles which prepared under optimized conditions i.e., polymer: drug ratio 1:6, agitation speed $1000 \mathrm{rpm}$ and stirring time 20 min were found to be spherical in shape, uniform in size and exhibited a smooth surface. The uniform size and smooth surface of microparticles was due to the tightening of the polymeric net work leading to shrinkage of the microcapsules as the time of evaporation of solvent increased. The optimum size of microcapsules were obtained with $20 \mathrm{~min}$ stirring time because larger time $30 \mathrm{~min}$ gave smaller microparticles and shorter time $15 \mathrm{~min}$ gave aggregated and less discreet microparticles. The surface morphology of microparticles prepared under optimized conditions was shown in Figure 5.

Data of average diameter and entrapment efficiency of all CA microparticles were compared (SSPS soft ware) to each other statistically using unpaired t-test and one-way analysis of variance (ANOVA) at a significant level $\mathrm{P} \leq 0.05$.

The flowability of microparticles was determined in terms of angle of repose and compressibility index (Table III) for its application in fabrication of sustained products. 
The angle of repose was found in the range of $23.5 \pm 0.4$ to $34.4 \pm 0.6^{\circ}$ and compressibility indices in the range $13.8 \pm 0.7$ to $23.6 \pm 0.6 \% \%$ suggesting good flowability of particles (Banker, Anderson, 1986).

The release studies of all microparticles (NIM-1 to NIM-3) were carried out by dissolution data in phosphate buffer $\mathrm{pH}$ 6.8. It is calculated as cumulative percent drug release and compared with conventional tablet (Figure 1). The cumulative percentage drug release in the formulation NIM-1, NIM-2, NIM-3 and conventional tablet (Con. tab.) was found to be $96.29 \pm 1.35,94.21 \pm 1.21,86.23 \pm 1.13$ and $93.29 \pm 0.52$ respectively. The drug release from conventional tablet was exhausted within $4 \mathrm{~h}$ while microparticles sustained the drug more than $14 \mathrm{~h}$. The study showed that cumulative percentage drug release is influenced by the

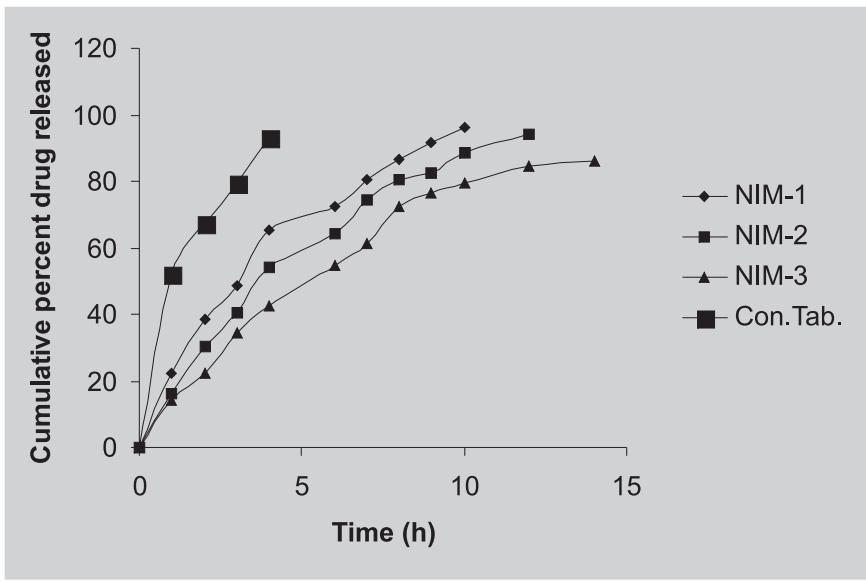

FIGURE 1 - Release profile of nimesulide from microparticles and conventional tablets.

NIM-1: Nimesulide microparticles of 1:9 polymer: drug ratio; NIM-2: Nimesulide microparticles of 1:6 polymer: drug ratio; NIM-3: Nimesulide microparticles of 1:3 polymer: drug ratio; Con.Tab.: Marketed conventional tablets of nimesulide microparticle size in all formulation and increase in release with decrease in microparticles size. This may be due to the presence of more drug molecules close to their surface in smaller particles for dissolution in the surrounding medium as compared to larger microparticles. In- vitro drug release data showed that $65.36 \pm 2.16-72.41 \pm 1.89,54.36 \pm 2.34-$ $64.29 \pm 1.48 \%$ nimesulide were released from NIM-1 and NIM-2 formulations respectively within 4- $6 \mathrm{~h}$ while only $42.56 \pm 1.68-54.89 \pm 2.14$ nimesulide was released from NIM-3 formulation. To observe the kinetic of drug release, the logarithm of percent drug retained in microparticles versus time was plotted and found straight line (Figure 2). It indicates that all microparticles follows first order release rate kinetic pattern (Table II). The first order regression equation and coefficient was shown in Table II. The

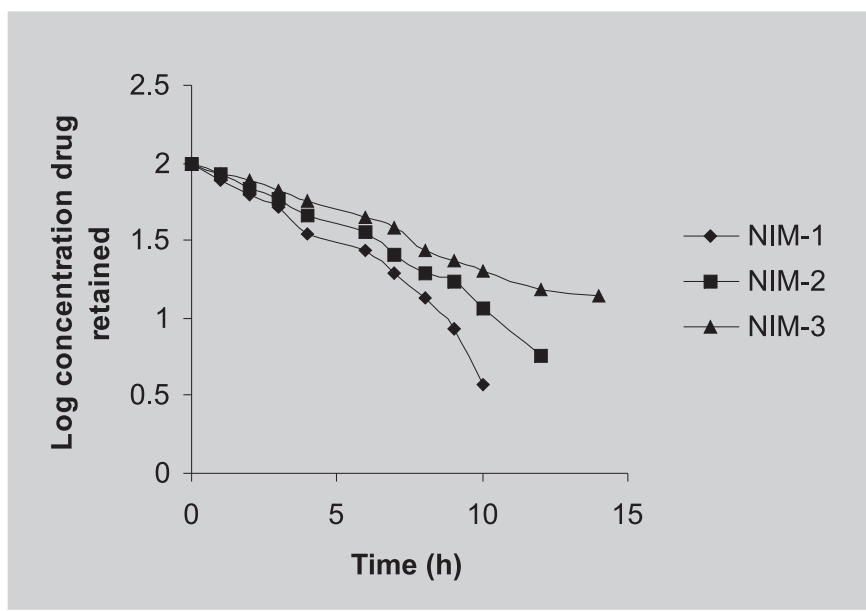

FIGURE 2 - First order kinetics of nimesulide microparticles.

NIM-1: Nimesulide microparticles of 1:9 polymer: drug ratio; NIM-2: Nimesulide microparticles of 1:6 polymer: drug ratio; NIM-3: Nimesulide microparticles of $1: 3$ polymer: drug ratio

TABLE II - Regression equation, regression co-efficient and first order release rate of cellulose acetate microparticles containing nimesulide

\begin{tabular}{|c|c|c|c|c|c|c|}
\hline S. No. & Formulation & $\begin{array}{l}\text { Polymer: } \\
\text { Drug Ratio }\end{array}$ & $\begin{array}{l}\text { Regression } \\
\text { coefficient }\left(r^{2}\right)^{a}\end{array}$ & $\begin{array}{l}\text { Release Rate } \\
\text { Constant } K_{1 \%}\left(\mathrm{hr}^{-1}\right)\end{array}$ & Equations $^{\text {b }}$ & $\begin{array}{l}\text { Regression } \\
\text { coefficient }\left(r^{2}\right)^{c}\end{array}$ \\
\hline 1 & NIM-1 & $1: 9$ & 0.9891 & 0.290 & $Y=-0.1263 X+2.0605$ & 0.9474 \\
\hline 2. & NIM-2 & $1: 6$ & 0.9910 & 0.225 & $Y=-0.0977 X+2.0513$ & 0.9787 \\
\hline 3. & NIM-3 & $1: 3$ & 0.9805 & 0.152 & $Y=-0.0663 X+2.0107$ & 0.9870 \\
\hline
\end{tabular}

${ }^{\mathrm{a}}$ Higuchi's regression coefficients; ${ }^{\mathrm{b}}$ First order regression coefficients; ${ }^{\mathrm{c}}$ First order kinetic equations 
TABLE III - Angle of repose and compressibility index of nimesulide microparticles (Mean \pm SD, n=3)

\begin{tabular}{|c|c|c|c|c|c|}
\hline S.No. & Polymer & Formulation & $\begin{array}{l}\text { Polymer: } \\
\text { Drug Ratio }\end{array}$ & $\begin{array}{l}\text { Angle of repose } \\
\theta \text { (degree) }\end{array}$ & $\begin{array}{l}\text { Compressibility } \\
\text { Index (I) }(\%)\end{array}$ \\
\hline 1 & & NIM-1 & $1: 9$ & $34.4 \pm 0.6$ & $23.6 \pm 0.6$ \\
\hline 2 & Cellulose acetate & NIM-2 & $1: 6$ & $23.5 \pm 0.4$ & $14.2 \pm 0.6$ \\
\hline 3 & & NIM-3 & $1: 3$ & $25.6 \pm 0.3$ & $13.8 \pm 0.7$ \\
\hline
\end{tabular}

dissolution data of all microparticles were fitted in Higuchi's model and found, that was linear $\left(\mathrm{r}^{2}\right.$ value, Table II) indicating diffusion controlled release from the polymer ( $\mathrm{Fi}$ gure 3).

The value of Higuchi's regression coefficient (r) of NIM-2 formulation was found to be more linear $(0.9910)$ than NIM-1 and NIM-3 formulation (Table II), and also maximum entrapment efficiency were obtained as compared to NIM-1 and NIM-3 microparticles (Table II). In vitro release data of NIM-2 microparticles were compared with available SR tablets as marketed reference in order to check the feasibility of prepared formulation for the further development of suitable and convenient multiple unit dosage forms with appropriate loading and maintenance dose. The in vitro data showed that NIM-2 microparticles have slower release $\left(\mathrm{K}_{1}=0.225 \% \mathrm{~h}^{-1}\right)$ than marketed SR tablet $\left(\mathrm{K}_{1}=0.371 \% \mathrm{~h}^{-1}\right)$. So NIM-2 microparticulate formulation may be utilized for the more extended period of drug release as a maintenance dose.

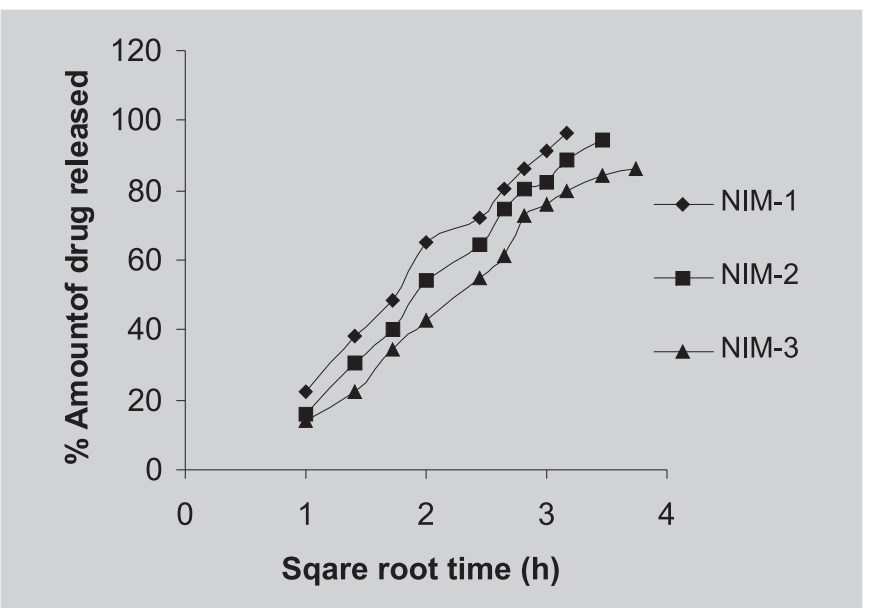

FIGURE 3 - Higuchi square root of time model for NIM1, NIM-2 and NIM-3 microparticles.

NIM-1: Nimesulide microparticles of 1:9 polymer: drug ratio; NIM-2: Nimesulide microparticles of 1:6 polymer: drug ratio; NIM-3: Nimesulide microparticles of 1:3 polymer: drug ratio
In order to make stable sustained product, the stability studies showed that microparticles are stable at $4 \pm 1^{\circ} \mathrm{C}(\mathrm{RT}), 25 \pm 1^{\circ} \mathrm{C}(\mathrm{RT})$ and $50 \pm 1^{\circ} \mathrm{C}(\mathrm{HT})$. The percentage residual drug content of the NIM-1, NIM-2 and NIM-3 microparticles were shown in Table IV at $4 \pm 1^{\circ} \mathrm{C}$ to $50 \pm 1^{\circ} \mathrm{C}$ after 7, 15 and 30 days of storage (Figure 4). No significant differences in percent residual drug content were observed at ambient and accelerated storage conditions in the prepared formulation indicating all formulations were stable under the stability studies.

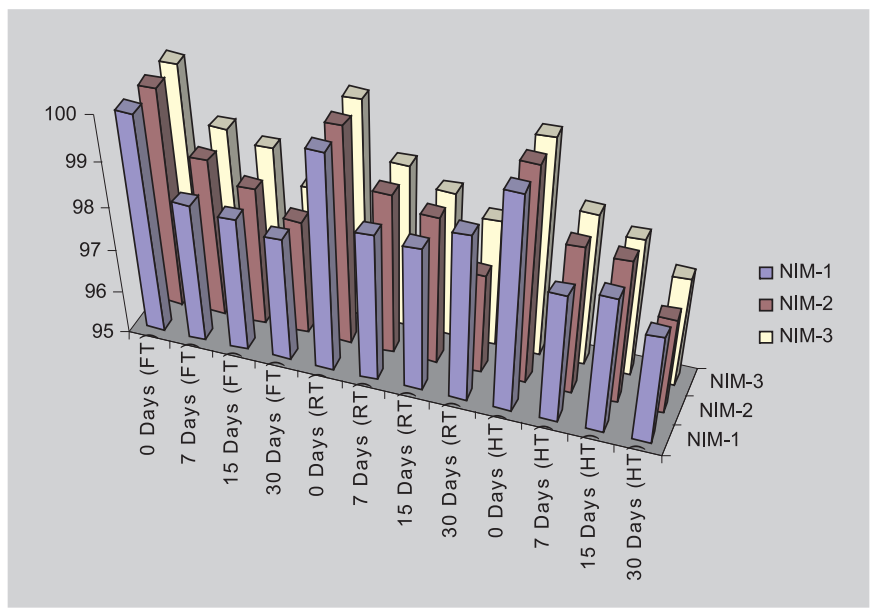

FIGURE 4 - Stability studies of nimesulide microparticles at $4 \pm 1(\mathrm{FT}), 25 \pm 1(\mathrm{RT}), 50 \pm 1(\mathrm{HT})^{\circ} \mathrm{C}$ after $0,7,15$ and 30 days storage.

NIM-1: Nimesulide microparticles of 1:9 polymer drug ratio; NIM-2: Nimesulide microparticles of 1:6 polymer drug ratio; NIM-3: Nimesulide microparticles of 1:3 polymer drug ratio

\section{CONCLUSION}

The study concluded that the processing variables; polymer: drug ratio, agitation speed and stirring time affects the preparation of sustained release nimesulide microparticles by an emulsion solvent evaporation process. 
TABLE IV - Percentage of nimesulide after stability studies of microparticles at $4 \pm 1(\mathrm{FT}), 25 \pm 1(\mathrm{RT}), 50 \pm 1(\mathrm{HT}){ }^{\circ} \mathrm{C}$

\begin{tabular}{lllllllllll}
\hline $\begin{array}{l}\text { Storage } \\
\text { (days) }\end{array}$ & \multicolumn{2}{l}{$\begin{array}{l}\text { Study at } 4 \pm 1{ }^{\circ} \mathrm{C}(\mathrm{FT}) \\
\text { Percentage of nimesulide }\end{array}$} & \multicolumn{2}{c}{ Study at $25 \pm 1{ }^{\circ} \mathrm{C}(\mathrm{RT})$} & \multicolumn{3}{c}{ Study at $50 \pm 1{ }^{\circ} \mathrm{C}(\mathrm{HT})$} \\
& NIM-1 & NIM-2 & NIM-3 & NIM-1 & NIM-2 & NIM-3 & NIM-1 & NIM-2 & NIM-3 \\
\hline 0 & 100 & 100 & 100 & 100 & 100 & 100 & 100 & 100 & 100 \\
& & & & & & & & & \\
7 & 98.22 & 98.65 & 98.79 & 98.44 & 98.74 & 98.79 & 98.02 & 98.74 & 98.57 \\
& \pm 0.38 & \pm 0.27 & \pm 0.23 & \pm 022 & \pm 0.38 & \pm 0.39 & \pm 0.34 & \pm 0.38 & \pm 0.28 \\
& & & & & & & & & \\
15 & 98.12 & 98.21 & 98.56 & 98.36 & 98.45 & 98.39 & 98.21 & 98.38 & 98.23 \\
& \pm 0.18 & \pm 0.64 & \pm 0.22 & \pm 0.37 & \pm 0.65 & \pm 0.18 & \pm 0.37 & \pm 0.46 & \pm 0.31 \\
& & & & & & & & & \\
30 & 97.89 & 97.68 & 97.85 & 98.89 & 97.35 & 97.98 & 97.56 & 97.28 & 97.56 \\
& \pm 0.69 & \pm 0.97 & \pm 0.44 & \pm 0.12 & \pm 0.22 & \pm 0.54 & \pm 0.41 & \pm 0.57 & \pm 0.82 \\
\hline
\end{tabular}

These variables not only influenced the morphology (Figure 5) but also affects on release of drug from the microparticles. The cellulose acetate could be a suitable polymer to give diffusion-controlled sustained formulation of nimesulide. Such sustained microparticles can also provide the flexibility to develop suitable dosage form for desired period of drug delivery as compared to available SR marketed formulation. Thus, it may improve safety, efficacy and patient compliance with reduced common cause of problem due to high dose absorption at once in conventional tablet.

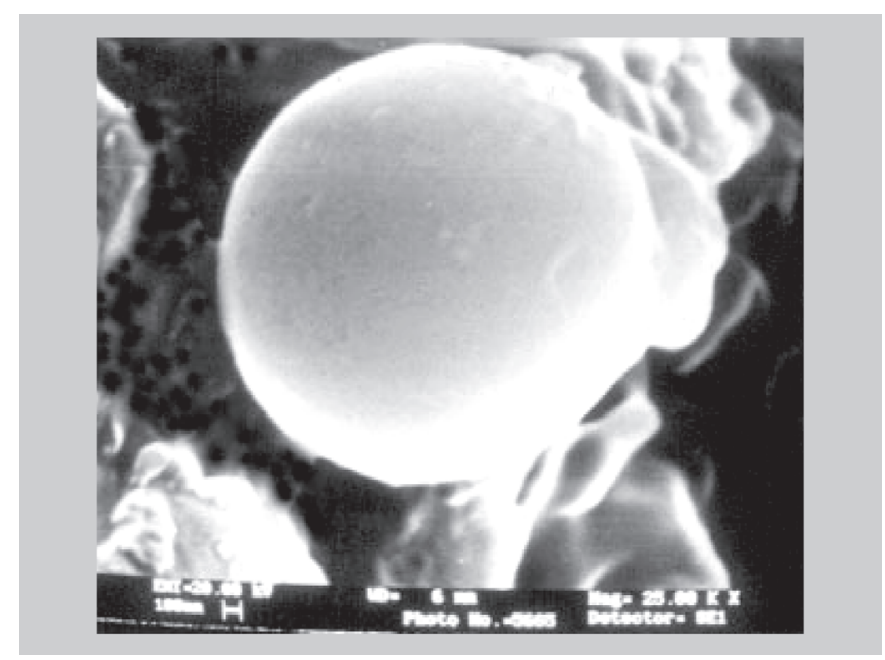

FIGURE 5 - Scanning electron micrograph of nimesulide microparticles ( $1: 6$ polymer: drug ratio)

\section{ACKNOWLEDGEMENT}

The authors gratefully acknowledge Nicholas Piramal India Ltd, Pithampur (M.P.) and Zim Lab. Nagpur
(M.H) for the supply of nimesulide and cellulose acetate. The authors wish to thank AICTE for providing UV and FTIR facility under the research promotion scheme and Chhattisgarh Council of Science and Technology (COST) and RPS (AICTE, New Delhi, folio No.8023/BOR/RPS $153 / 2006-07)$ for the financial assistance.

The authors also wish to thank Head, National Medical Library, New Delhi for providing library facility for literature survey.

\section{RESUMO}

\section{Efeito de variáveis do processo e estudo in vitro de sistema microparticulado de nimesulida}

Prepararam-se sistemas microparticulados de nimesulida (NIM) pelo método modificado de evaporação do solvente usando diferentes variáveis, tais como proporções polímero fármaco(NIM) (acetato de celulose, CA: nimesulida, NIM) (1:9, 1:6 e 1:3), velocidades de agitação (500-1500 rpm) e tempo de agitação (15-30 min). Os efeitos das variáveis do processo foram avaliados pelo tamanho da partícula e pela eficiencia no encapsulamento. O tamanho médio das micropartículas aumenta de $66,8 \pm 1,45$ a 87,3 $\pm 1,06$ um com o aumento na concentração de polímero, enquanto reduz com o aumento da velocidade e do tempo de agitação, mas velocidades mais altas resultam em partículas de formas irregulares. A eficácia de encapsulamento mais alta $(77,83 \pm 0,51 \%)$, uniformidade de tamanho, fluxo livre, isto é, ângulo de repouso $\left(23,5 \pm 0,4^{\circ}\right)$, e indice de compressibilidade $(14,2 \pm 0,6 \%)$, das micropartículas foram encontrados com a proporção de 1:6 (polímero:fármaco), a 1000 rpm e 20 min de tempo de agitação entre todas as micropartículas 
preparadas $(P \leq 0,05)$. O estudo da liberação do fármaco das micropartículas in vitro com variáveis do processo otimizadas (velocidade de agitação e tempo) foi desenvolvido e comparado com comprimidos convencionais e comercializados SR. O comprimido convencional libera o máximo de fármaco dentro de 4 h enquanto o sistema microparticulado libera em mais que $14 \mathrm{~h}$. Todas as formulações seguiram cinética de liberação de primeira ordem e liberação do fármaco controlada pela difusão (modelo de Higuchi). Estas microparticulas são estáveis à temperatura ambiente $\left(25 \pm 1^{\circ} \mathrm{C}\right)$, mas se aglomeram a temperaturas elevadas $\left(50 \pm 1{ }^{\circ} \mathrm{C}\right)$ por meio do amolecimento e fusão do polímero observada sob o estudo SEM.

UNITERMOS: Acetato de celulose. Microparticulas. Nimesulida.

\section{REFERENCES}

BANKER, G.S.; ANDERSON, N.R., Tablets. In: LACHMAN, L.; LIBERMAN, H.A.; KANIG, J.I., (Eds). The theory and practice of industrial pharmacy. Philadelphia, Lea and Febiger Publishers, 1986. p. 293345.

BAYOMI, M.A. Aqueous preparation and evaluation of albumin-chitosan microspheres containing indomethacin. Drug Dev. Ind. Pharm., v. 30, n. 4, p. 329-339, 2004.

BERNAREGGI, A. The pharmacokinetic profile of nimesulide in healthy volunteers. Drugs, v. 46, p. 64-72, 1993.

BOELSTERLI, U.A. Mechanisms of NSAID-induced hepato-toxicity: focus on nimesulide. Drug Saf., v. 25, n. 9, p. 633 - 648, 2002.

CHOWDHARY, K.P.R.; RAMESH, KV.R.N.S . Microencapsulation of solid dispersions of nifedipinenovel approach for controlling drug release. Indian Drug, v. 32, n. 10, p. $477,1995$.

DASHORA, K.; SARAF, S.; SARAF, S. In-vitro studies of tizanidine hydrochloride controlled release microcapsular matrices. Pak. J. Pharm. Sci., v. 19, n. 3, p. 177-181, 2006a.

DASHORA, K.; SARAF, S.; SARAF, S. Simultaneous spectrophotometric method for the determination of nimesulide and tizanidine hydrochloride. Orient. J. Chem., v. 22 , n. 1, p.167-168, 2006 b.
DASHORA, K.; SARAF, S.; SARAF, S. Effect of processing variables on micro particulate system of nimesulide. The Chinese Pharm. J., v. 58, p. 67-74, 2006c.

KULKARNI, S.K. On the safety of nimesulide, a preferential COX-2 inhibitor. Curr. Sci., v. 83, n.12, p.1442-1443, 2002.

MARTIN, A. Physical pharmacy. Philadelphia: Lea and Febiger Publishers, 1983. p. 414.

OLIVE, G.; REY, E. Effect of age and disease on the pharmacokinetics of nimesulide. Drugs, v. 46, n. Supp. 1, p. $73-78,1993$.

PERUCCA, E. Drug interactions with nimesulide. Drugs, v. 46, Suppl. 1, p. 79-82, 1993.

RABASSEDA, X. Nimesulide: A selective cyclooxygenase2 inhibitor anti-inflammatory drug. Drugs Today, v. 32, Suppl. D, p. 1-23, 1992.

SAJEEV, C.; VINAY, G.; ARCHNA, R.; SAHA, R. N. Oral controlled release formulation of diclofenac sodium by microencapsulation with ethyl cellulose. $J$. Microencapsul., v.19, n. 6, p. 753-60, 2002.

SARAF, S.; DASHORA, K.; SARAF, S. Effect of processing variables on microparticulate system of aceclofenac. Pak. J. Pharm. Sci., v. 19, n.1, p.1-6, 2006.

SARAVANAN, M.; BHASKAR, G.; SRINIVASA, RAO.; DHANARAJ, U. Ibuprofen-loaded ethyl cellulose/ polystyrene microspheres: an approach to get prolonged drug release with reduced burst effect and low ethylcellulose content. J. Microencapsul., v. 20, p. 289302, 2003.

SINGLA, A.K.; CHAWLA, M.; SINGH, A. Nimesulide: some pharmaceutical and pharmacological aspects- an update. J. Pharm. Pharmacol., v. 52, p. 467-486, 2000.

SOPPIMATH, K. S.; KULKARNI, A. R.; AMINABHAVIT. M.; BHASKAR, C. Cellulose acetate microspheres prepared by $\mathrm{o} / \mathrm{w}$ emulsification and solvent evaporation method, J. Microencapsul., v. 18, p. 811-817, 2001.

Recebido para publicação em 31 de outubro de 2006. Aceito para publicação em 23 de novembro de 2007. 